\title{
PENGARUH PEMBIAYAAN MUSYARAKAH, MARKET SHARE DAN MODAL INTELEKTUAL TERHADAP KINERJA KEUANGAN PADA BANK UMUM SYARIAH DI INDONESIA
}

\author{
Ayu Yunita ${ }^{1}$, Meutia Fitri ${ }^{* 2}$ \\ ${ }^{1,2}$ Program Studi Akuntansi Fakultas Ekonomi Universitas Syiah Kuala \\ e-mail: ayunita549@gmail.com ${ }^{1}$, meutia.fitri@unsyiah.ac.id ${ }^{* 2}$ \\ * Corresponding Author
}

\begin{abstract}
The purpose of this research is to examine the influence of musyarakah financing, market share, and intellectual capital to financial performance on islamic commercial banks in Indonesia in 2013-2018. The research type used is verificative research by using Purposive sampling method. The target population of this research are 14 islamic commercial banks in Indonesia and the sample of the research are islamic commercial banks. The data used in this research are secondary data, which are gotten from for the book year ended December 31, 2013, 2014, 2015, 2016, 2017, and 2018. The result of this research show that musyarakah financing, market share, and intellectual capital silmutaneously influence to financial performance. Partially, musyarakah financing has influence to financial performance, market share has influence to financial performance, and intellectual capital has influence to financial performance.
\end{abstract}

Keywords: Financial Performance, Financing, Intellectual Capital, Market Share

\section{Pendahuluan}

Bank syariah ialah jenis bank yang di dalam melaksanakan kegiatan operasionalnya merujuk pada hukum islam dan tidak ada membebankan bunga serta tidak membayar bunga kepada para nasabahnya. Bank syariah terus berkembang pesat di negara Indonesia, apalagi sejak disahkan Undang-Undang No. 21 Tahun 2008 yang membahas perihal Perbankan Syariah. Pasca berlakunya Undang-Undang tersebut, perbankan syariah di negara Indonesia mengalami perkembangan yang cukup signifikan, jika dilihat dari aspek jumlah bank, karyawan, komposisi pembiayaan, dan aset perbankan (Prasetiyo, 2012).

Pertumbuhan bank syariah yang cukup signifikan mempunyai dampak terhadap pembangunan nasional dan roda perekonomian negara Indonesia. Melihat betapa pentingnya peranan dari bank syariah, maka kinerja dari bank syariah perlu untuk ditingkatkan, supaya bank syariah tetap efisien dan sehat. Menurut berita dari kabarjatim, kinerja dari Bank Muamalat Indonesia pada tahun 2019 cenderung memburuk dan hal ini disebabkan karena adanya perlambatan pembiayaan (Saefullah, 2019). Menurut berita dari CNBC Indonesia, kinerja dari perbankan syariah masih lambat dan hal ini disebabkan karena adanya berbagai permasalahan seperti masalah penguatan modal, likuiditas, dan efisiensi (Hastuti, 2019).

Menurut berita dari finansial bisnis, kinerja dari bank syariah pada sembilan bulan tahun 2019 menunjukkan pelemahan dan jika dilihat dari aspek kinerja keuangannya, bank syariah mandiri (BSM) dan bank BNI syariah mengalami perlambatan di dalam pertumbuhan laba dan pertumbuhan kinerja, akan tetapi bank BCA syariah mengalami hal yang lebih parah. Bank BCA syariah mengalami perlambatan di dalam pertumbuhan kinerja bahkan bank tersebut belum bisa untuk mendapatkan level pertumbuhan sebesar 2 digit (Richard, 2019).

Cara untuk mengetahui kondisi dari kinerja keuangan di dalam bank syariah ialah dengan melihat dan menganalisis laporan keuangannya. Alat ukur yang bisa dipakai di dalam mengukur kinerja keuangan sebuah perbankan syariah ialah dengan menggunakan metode analisis rasio keuangan. Analisis dengan menggunakan rasio keuangan ialah 
sebuah perhitungan terhadap rasio keuangan yang bertujuan menilai bagaimana kondisi keuangan pada masa lampau, pada masa sekarang ini, dan bahkan pada masa yang akan datang. Secara umum rasio-rasio keuangan dapat dikategorikan ke dalam 5 rasio seperti rasio aktivitas, rasio pasar, rasio likuiditas, rasio leverage, dan juga rasio profitabilitas (Aisyiah, Darminto, \& Husaini, 2013).

Rasio profitabilitas ialah kemampuan sebuah perbankan untuk memperoleh laba. Analisis rasio profitabilitas pada perbankan syariah mempunyai tujuan yaitu untuk melihat dan mengukur tingkat efisiensi usaha yang dicapai suatu perbankan. Bank syariah dapat dikatakan mempunyai performa kinerja keuangan yang bagus apabila mempunyai tingkat profitabilitas yang tinggi. Dendawijaya \& Lukman (2005) telah membagi cara mengukur profitabilitas sebuah perbankan syariah ke dalam beberapa cara yaitu ROA dan ROE. ROA ialah salah satu rasio keuangan yang dapat menilai kemampuan sebuah perbankan syariah di dalam memanfaatkan keseluruhan dari total aset yang ada di dalam perbankan untuk mendapatkan keuntungan dan ROE hanya menghitung kemampuan sebuah perbankan syariah di dalam menghasilkan keuntungan melalui total ekuitas.

Otoritas Jasa Keuangan (OJK) sebagai badan yang bertugas untuk mengawasi dan membina perbankan syariah lebih memilih untuk mengukur nilai dari profitabilitas dengan menggunakan komponen aset, hal ini dikarenakan total aset perbankan syariah sebagian besar dananya berasal dari simpanan masyarakat. Dengan demikian, menghitung profitabilitas dengan menggunakan ROA sedikit lebih unggul daripada menggunakan ROE, karena ROA mampu untuk menghitung tingkat pengembalian ataupun keuntungan yang diterima oleh perbankan syariah dengan memperhitungkan nilai dari liabilitas, dana sirkah temporer dan ekuitas.

Menurut data dari Statistik Perbankan Syariah (SPS) tahun 2013-2018 terlihat bahwa ROA pada bank umum syariah (BUS) di negara Indonesia mengalami penurunan sangat drastis di tahun 2014, akan tetapi mampu untuk meningkat kembali pada tahun 20152017 dengan peningkatan yang tidak signifikan. Peningkatan ROA yang cukup signifikan terjadi pada tahun 2018. Menurut data dari SPS 2014, penurunan ROA pada tahun 2014 disebabkan adanya penurunan laba di dalam BUS dan penurunan tersebut terjadi secara sangat signifikan di dalam pendapatan non operasional. Selain mengalami penurunan pada pendapatan non operasional, BUS juga mengalami kerugian non operasional cukup tinggi yaitu senilai 4.269 Miliar Rupiah dan hal tersebut telah membuat BUS mengalami penurunan laba bersih di tahun 2014.

Setelah mengalami penurunan laba secara signifikan pada tahun 2014, BUS mulai kembali mengalami kenaikan laba pada tahun 2015 hingga pada 2018 secara perlahan-lahan. Menurut SPS 2018, adanya kenaikan laba pada tahun 2015 hingga 2018 salah satunya karena adanya penurunan pada beban non operasional yang sangat signifikan. Faktor lain yang kembali membuat laba pada BUS kembali meningkat ialah adanya peningkatan pada pendapatan operasional yang bersumber dari penyaluran dana.

Disebabkan karena adanya penurunan ROA yang sangat signifikan pada tahun 2014, peningkatan ROA yang tidak signifikan pada tahun 2015-2017 dan peningkatan ROA yang terjadi cukup signifikan pada tahun 2018, maka peneliti ingin menguji berbagai faktor yang dapat mempengaruhi peningkatan ROA pada BUS. Peningkatan ROA pada BUS dapat dipengaruhi oleh berbagai faktor seperti pembiayaan musyarakah, market share, dan modal intelektual (Lestari, Paramu, \& Sukarno, 2017; Puteri, Meutia, \& Yuniartie, 2014; Setyawati, 2016).

Salah satu faktor yang dapat mempengaruhi ROA adalah pembiayaan musyarakah (Faradilla, Arfan, \& Shabri, 2017; Nawawi, Nurdiansyah, \& Qodliyah, 2018; Romdhoni \& Yozika, 2018). Pembiayaan musyarakah dapat didefinisikan sebagai sebuah bentuk perjanjian kerja sama yang terjalin diantara kedua belah pihak ataupun lebih yang bertujuan untuk menjalankan suatu bisnis tertentu dan setiap pihak-pihak yang terlibat menyerahkan kontribusi dana ataupun manajerial sesuai dengan kesepatakan bersama, serta jika ada terdapat keuntungan atapun juga kerugian dibagi berdasarkan besaran porsi modal yang telah ditanamkan di dalam suatu bisnis (Dahlan, 2012 dalam Romdhoni \& Yozika, 2018).

Menurut data dari SPS 2018 dapat terlihat bahwa BUS menyalurkan pembiayaan musyarakah sebanyak $34 \%$ dari total pembiayaan syariah dan perkembangan pembiayaan musyarakah terus mengalami pertumbuhan dari tahun ke tahun. Pada 
penelitian ini peneliti menggunakan jenis pembiayaan akad musyarakah dikarenakan pembiayaan musyarakah lebih mencerminkan jati diri dari bank syariah dan pembiayaan akad musyarakah dapat menggambarkan jenis pembiayaan bagi hasil.

ROA pada BUS tidak hanya dapat dipengaruhi oleh pembiayaan musyarakah, akan tetapi ada faktor lain yaitu market share (Setyawati, 2016; Belkhaoui et al., 2014; Rofiatun, 2016; Samad, 2008). Market share ialah kunci untuk menentukan profitabilitas suatu perbankan, perbankan yang mempunyai market share yang besar tentu dapat memberikan kepuasan kepada konsumen dan akan dapat menikmati keunggulan kompetitif (Setyawati, 2016). Market share termasuk ke dalam faktor eksternal yang dapat mempengaruhi tingkat keuntungan di sebuah perbankan, maka peneliti ingin menguji seberapa besar pengaruh dari faktor ekternal terhadap ROA pada BUS. Market share digunakan untuk mengukur kinerja keuangan pada sebuah perbankan syariah masih terbilang baru di Indonesia, market share yang tinggi akan membuat semakin tinggi pula fungsi dan peran dari perbankan syariah terhadap perekonomian nasional (Rohman \& Karsinah, 2016).

ROA juga dapat dipengaruhi oleh modal intelektual (Lestari, Paramu, \& Sukarno, 2017; Ousama \& Fatima, 2015). Modal intelektual dapat diartikan sebagai sebuah istilah yang diberikan pada kombinasi dari berbagai aset yang tidak berwujud, karyawan dan property intelektual, serta infrastruktur yang dapat memungkinkan sebuah perusahaan untuk bisa berfungsi (Brooking, 1996 dalam Ulum, 2015:68). Modal intelektual juga dapat dikatakan sebagai pengetahuan yang dipunya sama perusahaan ataupun seorang individu yang dapat memberikan kontribusi terhadap keberlangsungan keunggulan kompetitif sebuah perusahaan (Bontis, 2000). Dapat dikatakan semakin tinggi nilai modal intelektual suatu perusahaan akan membuat semakin tinggi juga kemampuan sebuah perusahaan untuk mencapai tingkat profitabilitas (Muhammad \& Ismail, 2009).

Pada negara Indonesia, mulai berkembangnya fenomena mengenai modal intelektual di saat adanya PSAK nomor 19 (revisi tahun 2000) yang membahas mengenai aset yang tidak berwujud. Di dalam pernyataan standar akuntansi keuangan tersebut sebenarnya tidaklah disebutkan dengan jelas membahas mengenai modal intelektual, akan tetapi lebih kurang topik mengenai modal intelektual sudah mendapatkan sebuah perhatian (Ikatan Akuntan Indonesia, 2002). Berdasarkan penjelasan tersebut dapat dikatakan modal intelektual sebagai sebuah bagian dari aset yang tidak berwujud, akan tetapi salah satu dari komponen modal intelektual yakni modal manusia ataupun human capital tidak dapat dikatakan sebagai aset tidak berwujud, hal ini disebabkan human capital tidak memenuhi suatu karakteristik dari aset yang tidak berwujud.

Berdasarkan latar belakang tersebut dan disebabkan karena adanya research gaps, maka penulis meneliti mengenai "Pengaruh Pembiayaan Musyarakah, Market share dan Modal Intelektual terhadap Kinerja Keuangan pada Bank Umum Syariah di Indonesia)."

\section{Kerangka Teoritis Dan Pengembangan Hipotesis}

Bank Syariah

Bank syariah ialah jenis bank yang di dalam melaksanakan kegiatan operasionalnya merujuk pada hukum islam dan tidak ada membebankan bunga serta tidak membayar bunga kepada para nasabahnya (Ismail, 2016). Peneliti memfokuskan menggunakan BUS sebagai objek dari penelitian ini. BUS ialah jenis bank yang di dalam melaksanakan berbagai kegiatan usahanya menggunakan prinsip syariah dan kegiatannya memberikan jasa di dalam lalu lintas pembayaran (Ascarya \& Yumanita, 2005).

\section{Kinerja Keuangan}

Kinerja keuangan ialah sebuah analisis yang memiliki tujuan untuk mengevaluasi bagaimana kinerja keuangan sebuah perusahaan pada masa lalu (Endri \& Wakil, 2008). Kinerja keuangan sebuah perbankan syariah dapat diukur melalui analisis laporan keuangan. Di dalam penelitian ini, peneliti berfokus pada analisis rasio profitabilitas yaitu ROA untuk melihat kinerja keuangan BUS. ROA ialah salah satu rasio profitabilitas yang bisa mengukur total laba yang didapatkan oleh sebuah perbankan dari tiap rupiah aset yang ada di dalam suatu perbankan.

\section{Pembiayaan Musyarakah}

Pembiayaan musyarakah juga dapat didefinisikan sebagai sebuah bentuk perjanjian kerja sama yang terjalin diantara kedua belah pihak ataupun 
lebih yang bertujuan untuk menjalankan suatu bisnis tertentu dan setiap pihak-pihak yang terlibat menyerahkan kontribusi dana ataupun manajerial sesuai dengan kesepatakan bersama, serta jika ada terdapat keuntungan atapun juga kerugian dibagi berdasarkan besaran porsi modal yang telah ditanamkan di dalam suatu bisnis (Dahlan, 2012 dalam Romdhoni \& Yozika, 2018).

\section{Market share}

Market share ialah pasar yang dikuasai oleh perusahaan dan adanya kenaikan market share suatu perusahaan dapat bermakna bahwa suatu perusahaan bisa melampaui para kompetitornya dan begitupun sebaliknya. Pada penelitian ini, peneliti menggunakan total pendanaan dari pihak ketiga sebagai indikator untuk menghitung market share perbankan syariah.

\section{Modal Intelektual}

Modal intelektual ialah pengetahuan yang dipunya sama perusahaan ataupun seorang individu yang dapat memberikan kontribusi terhadap keberlangsungan keunggulan kompetitif sebuah perusahaan (Bontis, 2000) dan ada yang mengartikan modal intelektual sebagai packaged useful knowledge (Stewart, 1997 dalam Ulum, 2009:20). Adapun teori yang mendukung modal intelektual ialah Resources Based View (RBV).

Berbagai kesatuan komponen dari modal intelektual yang ada di dalam penelitian ini ialah: "Pertama, human capital ialah salah satu yang menjadi faktor penentu dari produktivitas perusahaan dan human capital ini ialah dimensi kualitatif daripada SDM yang termasuk keterampilan dan juga keahlian yang dapat mempengaruhi kemampuan dari produktif para pekerja di sebuah perusahaan serta human capital dapat ditingkatkan dengan melalui pelatihan dan pendidikan (Farah \& Sari, 2014). Kedua Structural capital ini bisa diartikan sebagai kemampuan sebuah perusahaan di dalam memenuhi proses rutinitasnya dan juga strukturnya yang mendukung usaha para pekerja mereka untuk dapat menghasilkan sebuah kinerja intelektual yang optimal (Sawarjuwono \& Kadir, 2003). Dan ketiga Capital employed dapat dijelaskan sebagai total modal yang telah dimanfaatkan di dalam aset lancar dan juga aset tetap di dalam suatu perusahaan. Capital employed juga dapat diartikan sebagai sebuah indikator dari suatu nilai tambah dari modal yang telah dipakai di dalam perusahaan. Nilai dari modal kerja tersebut dapat memberikan gambaran mengenai seberapa banyak sebuah nilai tambah yang dapat diciptakan oleh suatu perusahaan dari modal yang telah dipakai di dalam perusahaan (Mehri, Umar, Saeidi, Hekmat, \& Naslmosavi, 2013).”

\section{Kerangka Pemikiran}

\section{Pengaruh Pembiayaan Musyarakah Terhadap Kinerja Keuangan Pada Bank Umum Syariah}

Perbankan yang menyalurkan pembiayaan musyarakah akan memperoleh pendapatan dan diharapkan akan dapat meningkatkan profitabilitas perbankan tersebut yang tercermin dari peningkatan perolehan laba. Penyaluran pembiayaan musyarakah akan membuat pihak perbankan syariah akan mendapatkan keuntungan yang berupa bagi hasil laba. Semakin tinggi perolehan keuntungan bagi hasil laba dari pembiayaan musyarakah akan bisa berdampak pada tingginnya profit/ keuntungan yang didapatkan suatu bank syariah, sehingga dengan tingginya profit yang didapatkan bisa berdampak pada tingkat profitabilitas dan juga berdampak pada kinerja keuangan pada bank syariah (Firdaus dan Ariyanti, 2009:2 dalam Muslim (2015).

Menurut peneliti, pembiayaan musyarakah merupakan salah satu sumber pendapatan bagi perbankan syariah dan hal ini dikarenakan perbankan syariah yang memberikan pembiayaan dalam bentuk akad musyarakah akan mendapatkan pendapatan musyarakah berdasarkan kesepakatan antara pihak perbankan dengan nasabahnya, dan keuntungan tersebut didasarkan atas hasil dari sebuah bisnis/usaha tertentu. Dengan demikian, semakin tinggi pembiayaan musyarakah yang diberikan oleh perbankan kepada nasabahnya, maka semakin tinggi pula tingkat pendapatan yang akan didapatkan oleh perbankan syariah itu sendiri.

Telah ada beberapa peneliti yang sudah melakukan penelitian tentang pengaruh dari pembiayaan musyarakah terhadap kinerja keuangan pada perbankan syariah, seperti penelitian Anjani \& Hasmarani (2016) yang menyatakan bahwasannya pembiayaan musyarakah mempunyai pengaruh yang positif terhadap kinerja keuangan pada perbankan syariah. Berbeda dengan penelitian Anjani \& Hasmarani (2016), penelitian dari Puteri, Meutia, \& 
Yuniartie (2014) dan Faradilla, Arfan, \& Shabri (2017) justru menyatakan bahwasannya pembiayaan musyarakah dapat berpengaruh secara negatif terhadap kinerja keuangan pada perbankan syariah.

Hal yang menyebabkan pembiayaan musyarakah berpengaruh negatif terhadap kinerja keuangan ialah proporsi dari pembiayaan musyarakah masih tergolong rendah jika dibandingkan dengan jenis pembiayaan lainnya dan lemahnya peranan pembiayaan musyarakah dapat disebabkan karena internal bank syariah itu sendiri dan "menurut Saeed (2003) dalam Puteri, Meutia, \& Yuniartie (2014) mengungkapkan beberapa faktor yang menyebabkan lemahnya pengaruh pembiayaan musyarakah, sehingga dapat membuat penurunan pada tingkat ROA, yaitu seperti: pertama, adanya pemikiran bahwa standar moral yang berkembang di kebanyakan komunitas muslim tidak memberi kebebasan penggunaan pembiayaan musyarakah sebagai mekanisme investasi sehingga mendorong bank untuk mengadakan pemantauan lebih intensif terhadap setiap investasi yang diberikan. Hal ini membuat operasional perbankan berjalan tidak ekonomi dan tidak efisien."

"Kedua, Keterkaitan bank dalam pembiayaan sistem bagi hasil untuk membantu perkembangan usaha lebih banyak melibatkan pengusaha secara langsung daripada sistem lainnya pada bank konvensional. Besar kemungkinan pihak bank turut mempengaruhi setiap pengambilan keputusan bisnis mitranya. Pada sisi lain, keterlibatan yang tinggi ini akan mengecilkan naluri pengusaha yang sebenarnya lebih menuntut kebebasan yang luas daripada campur tangan dalam penggunaan dana yang dipinjamkan."

"Ketiga, pemberian pembiayaan berdasarkan sistem bagi hasil memerlukan kewaspadaaan yang lebih tinggi dari pihak bank. Bank syariah kemungkinan besar meningkatkan kualitas pegawainya dengan cara mempekerjakan para teknisi dan ahli manajemen untuk mengevaluasi proyek usaha yang dipinjami untuk mencermati lebih teliti dan lebih jeli daripada teknis peminjaman pada bank konvensional. Hal ini akan meningkatkan biaya yang dikeluarkan oleh para banker dalam menjaga efisiensi kinerja perbankannya."

"Keempat Pemberian pembiayaan dengan sistem bagi hasil, apabila terjadi kerugian maka bank akan ikut menanggung kerugian bisnis yang dijalankan pengusaha. Kesanggupan untuk turut menanggung risiko ini, kemungkinan akan mendorong investasi lebih berisiko. Sehingga, dapat disimpulkan bahwa pengelolaan pembiayaan musyarakah lebih sulit jika dibandingkan dengan jenis pembiayaan pada akad lainnya dan tentunya dapat menimbulkan biaya yang besar juga bagi bank syariah. Apabila biaya yang dikeluarkan oleh bank syariah untuk mengelola pembiayaan musyarakah lebih tinggi daripada jenis pembiayaan yang lainnya, maka dapat membuat pendapatan yang akan diterima oleh bank syariah menjadi berkurang ataupun belum optimal. Oleh sebab itu, pengaruh dari pembiayaan musyarakah dapat mengakibatkan pada penurunan ROA pada bank syariah Puteri, Meutia, \& Yuniartie (2014).”

\section{Pengaruh Market share Terhadap Kinerja Keuangan Pada Bank Umum Syariah}

Sebuah perusahaan yang mempunyai market share yang tinggi bisa memberikan kepuasan kepada para konsumennya dan juga akan bisa menikmati keunggulan kompetitif (Schahwabach, 1991 dalam Setyawati, 2016) dan market share ialah kunci untuk menentukan profitabilitas suatu perusahaan (Setyawati, 2016). Peran dari market share ialah sumber laba bagi sebuah perusahaan (Arize et al., 2008 dalam Maghfuriyah, Azam, \& Shukri, 2019). Bahkan berdasarkan teori structure conduct performance (SCP), market share telah membuat sebuah perusahaan mempunyai kinerja yang lebih baik, sehingga selanjutnya akan mempunyai dampak terhadap profitabilitas perusahaan tersebut.

Market share yang besar bisa memberikan berbagai keuntungan kepada perusahaan, termasuk dengan tingkat konsumen yang menggunakan produk perusahaan. Pada umumnya, semakin banyak konsumen yang menggunakan produk suatu perusahaan, maka akan bisa memberikan tambahan keuntungan untuk perusahaan (Ibrahim, Nuzula, \& Nurlaily, 2019). Pertumbuhan pasar akan dapat memberikan pertambahan besarnya market share, sehingga hal ini akan memberikan dampak pada meningkatnya penjualan dan juga keuntungan untuk jangka panjang suatu perusahaan serta tingginya market share juga akan memberikan dampak positif terhadap tingkat ROA suatu perusahaan (Guiltinan, 1985:387 dalam Ibrahim, Nuzula, \& Nurlaily, 2019). Heggested (1977) dan Mullineaux (1978) dalam Obeidat, El-Rimawi, Masa'deh, Maqableh, \& Al- 
Jarrah (2013) berpendapat bahwa market share berbanding terbalik dengan tingkat profitabilitas.

Menurut peneliti, perbankan syariah yang mempunyai market share dana pihak ketiga yang tinggi akan dapat mempunyai tingkat profitabilitas yang tinggi pula. Hal ini dikarenakan, semakin besar market share DPK, maka bank akan semakin banyak mendapatkan dana dari nasabahnya. Perbankan syariah yang memiliki market share DPK yang tinggi, tentu punya lebih banyak dana jika dibandingkan dengan bank syariah yang mempunyai market share DPK yang lebih kecil. Bank yang mempunyai banyak dana tentu mempunyai kesempatan untuk menawarkan lebih banyak produk pembiayaan kepada para masyarakat. Dengan demikian perbankan tersebut akan dapat memperoleh keuntungan pada setiap bulannya. Selain itu, perbankan yang membuat market share dana pihak ketiga yang tinggi juga dapat dengan leluasa untuk mengembangkan usahanya, karena mereka mempunyai dana yang cukup. Bank yang mempunyai market share DPK yang tinggi dapat mempunyai kinerja keuangan yang bagus apabila bank tersebut mampu untuk mengelola dananya dengan cukup baik dan efisien di dalam mengelolanya. Apabila bank tidak pandai dan tidak bagus di dalam mengelola dana yang telah mereka dapatkan, maka bank tersebut akan dapat menurunkan kinerja keuanganya.

Telah ada beberapa peneliti yang sudah melakukan penelitian tentang pengaruh dari market share terhadap kinerja keuangan, seperti penelitian Belkhaoui et al., (2014) yang menyatakan bahwasannya market share mempunyai pengaruh yang positif terhadap kinerja keuangan pada perbankan syariah. Berbeda dengan penelitian Belkhaoui et al., (2014), penelitian dari Setyawati (2016); Sudana \& Sulistyowati (2010); Ibrahim et al., (2019) justru menyatakan bahwasannya market share dapat berpengaruh secara negatif terhadap kinerja keuangan.

Hal yang menyebabkan market share mempunyai pengaruh yang negatif terhadap kinerja keuangan ialah "pembiayaan yang dilakukan oleh bank mengandung resiko, sehingga akan mempengaruhi profitabilitasnya. Sampel dalam penelitian Ibrahim et al., (2019) menunjukkan beberapa bank yang mengalami peningkatan pangsa pasar dan diikuti dengan penurunan ROA. Contohnya pada Bank BCA Syariah tahun 2011 - 2012, tahun
2011 pangsa pasar sebesar 0,66\% dengan ROA sebesar $0,85 \%$. Tahun berikutnya pangsa pasar meningkat jadi $0,68 \%$ dengan ROA turun menjadi $0,77 \%$. Sejalan dengan kondisi tersebut, penelitian yang dilakukan Fahmi (2012) dalam Ibrahim et al., (2019) menyatakan bahwa seharusnya bank umum syariah tidak mengedepankan market share untuk mendapatkan laba, hal ini dikarenakan tingkat keuntungan bank syariah lebih bersumber dari tingkat efisiensi daripada tingkat konsentrasi pasar dan penguasaan pasar."

\section{Pengaruh Modal Intelektual Terhadap Kinerja Keuangan Pada Bank Umum Syariah}

Modal intelektual termasuk suatu sumber daya berharga untuk memperoleh keunggulan kompetitif, maka oleh sebab itu variabel modal intelektual dapat berkontribusi pada peningkatan kinerja keuangan sebuah perusahaan (Kehelwalatenna \& Gunaratne, 2010). Semakin besar nilai dari suatu modal intelektual yang dimiliki oleh sebuah perusahaan, akan semakin besar pula kemampuan sebuah perusahaan untuk mencapai profitabilitas. Selanjutnya, modal intelektual dapat dikatakan sebagai aset perusahaan, hal ini dikarenakan modal intelektual dapat memberikan suatu keunggulan kompetitif dan juga memberikan kinerja keuangan yang superior (Barney, 1991 dalam Nawaz, 2017).

Modal intelektual dapat diyakini mempunyai fungsi yang cukup signifikan di dalam usaha untuk meningkatkan nilai perusahaan ataupun juga kinerja keuangan sebuah perusahaan (Lestari et al., 2017). Bahkan sebuah perusahaan yang bisa mengelola berbagai sumber daya intelektual yang ada di dalam perusahaannya diyakini bisa menciptakan sebuah nilai tambah serta akan dapat menghasilkan keunggulan bersaing, tentunya dengan melakukan berbagai penelitian, inovasi, dan juga pengembangan yang pada akhirnya dapat berdampak terhadap peningkatan kinerja keuangan perusahaan (Lestari et al., 2017).

Menurut peneliti, sebuah perusahaan yang mempunyai modal intelektual yang besar bisa cenderung mempunyai kinerja keuangan yang baik juga. Modal intelektual akan dapat menciptakan keunggulan bersaing bagi perusahaan. Sesuai dengan konsep RBV, yaitu sebuah perusahaan yang mempunyai berbagai sumber daya yang bisa membuat perusahaan tersebut mempunyai keunggulan bersaing, 
akan bisa mengarahkan sebuah perusahaan untuk mempunyai kinerja keuangan yang baik lagi pada jangka panjang (Ulum, 2015:20).

Telah ada beberapa peneliti yang sudah melakukan penelitian tentang pengaruh dari modal intelektual terhadap kinerja keuangan, seperti penelitian Ousama \& Fatima (2015); Bustamam \& Aditia (2016) yang menyatakan bahwasannya modal intelektual mempunyai pengaruh yang positif terhadap kinerja keuangan.

Berdasarkan penjelasan sebelumnya, maka kerangka pemikiran dapat dilihat pada gambar berikut ini:

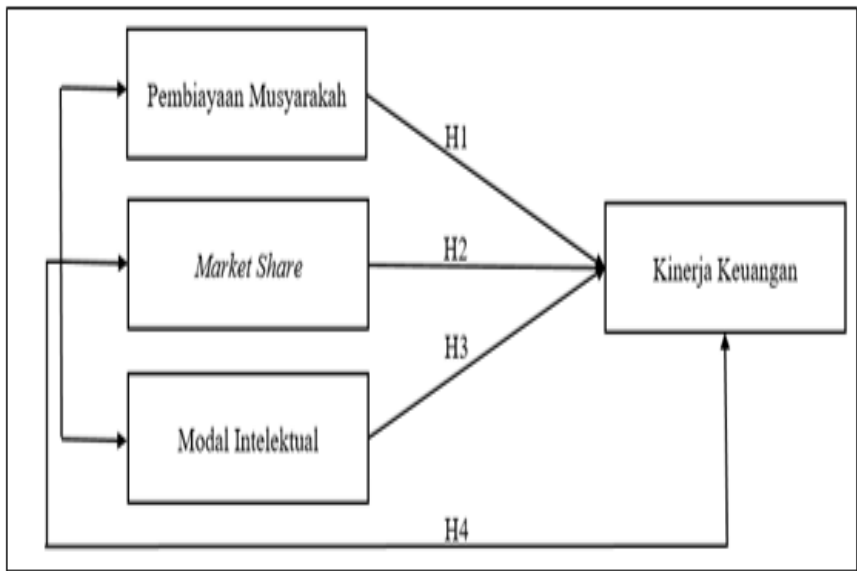

\section{Hipotesis}

Berdasarkan penjelasan yang sudah diuraikan sebelumnya, dapat tercipta berbagai hipotesis yaitu sebagai berikut ini:

\begin{tabular}{|c|l|}
\hline H1 & $\begin{array}{l}\text { : Pembiayaan musyarakah berpengaruh } \\
\text { terhadap kinerja keuangan pada bank umum } \\
\text { syariah. }\end{array}$ \\
\hline H2 & $\begin{array}{l}\text { : Market share berpengaruh terhadap kinerja } \\
\text { keuangan pada bank umum syariah. }\end{array}$ \\
\hline H3 & $\begin{array}{l}\text { : Modal intelektual berpengaruh terhadap } \\
\text { kinerja keuangan pada bank umum syariah. }\end{array}$ \\
\hline H4 & $\begin{array}{l}\text { : Pembiayaan musyarakah, market share dan } \\
\text { modal intelektual berpengaruh secara } \\
\text { simultan terhadap kinerja keuangan pada } \\
\text { bank umum syariah. }\end{array}$ \\
\hline
\end{tabular}

\section{Metode Penelitian}

\section{Desain Penelitian}

Tabel Berikut dapat menjelaskan desain penelitian yang ada di dalam penelitian ini.

\begin{tabular}{|l|l|}
\hline Tujuan Penelitian & : Pengujian Hipotesis \\
\hline Tingkat Intervensi & : Minimal \\
\hline Situasi Studi & : Tidak Diatur \\
\hline Unit Analisis & : Organisasi \\
\hline Horizon Waktu & : Data Panel Unbalanced \\
\hline
\end{tabular}

\section{Populasi dan Sampel Penelitian}

Di dalam penelitian ini, peneliti memilih kesemua BUS yang ada di Indonesia untuk menjadi populasi dan peneliti menggunakan teknik purposive sampling di dalam menentukan sampel. Populasi BUS yang sesuai dengan semua kriteria tertentu tersebut yang bisa menjadi sampel di dalam penelitian ini. Tabel berikut dapat menjelaskan berbagai kriteria tertentu yang ada di dalam penelitian ini.

\begin{tabular}{lc}
\hline \multicolumn{1}{c}{ Kriteria Sampel } & Jumlah Perbankan \\
\hline BUS di Indonesia yang terdaftar di OJK tahun 2013-2018 & 14 \\
BUS yang tidak menyalurkan pembiayaan musyarakah 2013- & (1) \\
2018 & 13 \\
Jumlah sampel BUS di Indonesia & 13 \\
\hline
\end{tabular}

Sumber: Data diolah (2020)

Bersumber pada tabel tersebut, maka BUS yang dapat memenuhi berbagai kriteria diatas ialah sebanyak 13 BUS. Tabel berikut menampilkan berbagai daftar sampel di dalam penelitian ini.

\begin{tabular}{|c|l|}
\hline No. & \multicolumn{1}{|c|}{ Bank Umum Syariah } \\
\hline 1. & PT. Bank Aceh Syariah \\
\hline 2. & PT. BPD Nusa Tenggara Barat Syariah \\
\hline 3. & PT. Bank Muamalat Indonesia \\
\hline 4. & PT. Bank Victoria Syariah \\
\hline 5. & PT. Bank BRISyariah \\
\hline 6. & PT. Bank Jabar Banten Syariah \\
\hline 7. & PT. Bank BNI Syariah \\
\hline 8. & PT. Bank Syariah Mandiri \\
\hline 9. & PT. Bank Mega Syariah \\
\hline 10. & PT. Bank Panin Dubai Syariah \\
\hline 11. & PT. Bank Syariah Bukopin \\
\hline 12. & PT. BCA Syariah \\
\hline 13. & PT. Maybank Syariah Indonesia \\
\hline
\end{tabular}

Sumber: Data Peneliti 2020

\section{Sumber dan Teknik Pengumpulan Data}

Pada penelitian ini, peneliti menggunakan jenis data sekunder yang berupa data laporan keuangan akhir tahun dan data tersebut didapatkan oleh peneliti pada website masing-masing sampel penelitian. Pada penelitian ini, peneliti memilih metode pengumpulan data yang berupa metode dokumentasi.

\section{Operasionalisasi Variabel Variabel Dependen}

Di dalam penelitian ini yang menjadi variabel dependen ialah kinerja keuangan yang diukur dengan menggunakan ROA. Rumus untuk menghitung ROA (Bustamam \& Aditia, 2016) yakni:

ROA $=\frac{\text { Laba Sebelum Pajak }}{\text { Total Aset }} \times 100 \%$




\section{Variabel Independen}

\section{Pembiayaan Musyarakah}

Pembiayaan musyarakah juga dapat didefinisikan sebagai sebuah bentuk perjanjian kerja sama yang terjalin diantara kedua belah pihak ataupun lebih yang bertujuan untuk menjalankan suatu bisnis tertentu dan setiap pihak-pihak yang terlibat menyerahkan kontribusi dana ataupun manajerial sesuai dengan kesepatakan bersama, serta jika ada terdapat keuntungan atapun juga kerugian dibagi berdasarkan besaran porsi modal yang telah ditanamkan di dalam suatu bisnis (Dahlan, 2012 dalam Romdhoni \& Yozika, 2018). Rumus untuk menghitung pembiayaan musyarakah (Faradilla et al., 2017) yakni:

$\begin{aligned} & \text { Pembiayaan } \\ & \text { Musyarakah }\end{aligned}=\frac{\text { Pembiayaan Musyarakah }}{\text { Total Pembiayaan }} \times 100 \%$

\section{Market share}

Market share ialah pasar yang dikuasai oleh perusahaan dan adanya kenaikan market share suatu perusahaan dapat bermakna bahwa suatu perusahaan bisa melampaui para kompetitornya dan begitupun sebaliknya. Rumus untuk menghitung market share (Belkhaoui et al., 2014) yakni:

$\begin{gathered}\text { Market } \\ \text { share }\end{gathered}=\begin{gathered}\text { Total Dana Pihak Ketiga } \\ \text { Total Dana Pihak Ketiga } \\ \text { Seluruh BUS }\end{gathered} \times 100 \%$

\section{Modal Intelektual}

Modal intelektual ialah pengetahuan yang dipunya sama perusahaan ataupun seorang individu yang dapat memberikan kontribusi terhadap keberlangsungan keunggulan kompetitif sebuah perusahaan (Bontis, 2000) dan modal intelektual diukur dengan menggunakan metode Pulic 1997. Rumus untuk menghitung modal intelektual antara lain sebagai berikut ini:

$$
\mathrm{VAIC}^{\mathrm{TM}}=\mathrm{HCE}+\mathrm{SCE}+\mathrm{CEE}
$$

\section{Metode Analisis Data}

\section{Pengujian Statistik Deskriptif}

Statistik deskriptif ini dapat berfungsi untuk menjelaskan berbagai variabel-variabel yang ada di dalam sebuah penelitian. "Menurut Ghozali (2006), statistik deskriptif bisa memberikan sebuah deskripsi mengenai suatu data yang dapat dilihat dari standar deviasi, rata-rata, minimum dan juga maksimum. Melalui statistik deskriptif ini, peneliti dapat melihat gambaran dari data peneliti, dan juga akan didapatkan berbagai informasi yang cukup jelas yang mengenai pengaruh dari pembiayaan musyarakah, market share, dan modal intelektual terhadap kinerja keuangan pada bank umum syariah.”

\section{Pengujian Asumsi Klasik \\ Pengujian Multikolinearitas}

"Di dalam penelitian ini menggunakan pengujian multikolonieritas yang bertujuan untuk melakukan pengujian apakah model regresi ditemukan adanya korelasi diantara variabel bebasnya, dan caranya ialah dengan melihat Variance Inflation Factor (VIF) dan juga melihat nilai Tolerance. Suatu model regresi ada menunjukkan terjadinya multikolonearitas, apabila besarnya nilai VIF lebih besar dari 10 ataupun besarnya nilai Tolerance lebih kecil dari 0.10 (Imam Ghozali, 2006:91)."

\section{Pengujian Normalitas}

"Di dalam penelitian ini menggunakan pengujian normalitas yang bertujuan untuk melakukan pengujian apakah di dalam model regresi, variabel residual ataupun pengganggu mempunyai distribusi normal, dan cara untuk mengetahui apakah data berdistribusi normal atau sebaliknya ialah dengan melakukan pengujian statistic non-parametrik Kolmogorov-Smirnov ataupun sering disingkat K-S. Sebuah data yang berdistribusi normal apabila hasil dari pengujian statistic non-parametrik dari K-S ada menunjukkan bahwa nilai signifikannya berada diatas 0,05 (Imam Ghozali, 2006:110).”

\section{Pengujian Heteroskedastisitas}

"Di dalam penelitian ini menggunakan pengujian heteroskedastisitas yang bertujuan untuk melakukan pengujian apakah di dalam model regresi ada terjadi ketidaksamaan variance dari residual satu pengamatan ke pengamaan yang lainnya, dan cara untuk mengetahui apakah ada terjadi heteroskedastisitas atau tidak ada terjadi heteroskedastisitas ialah dengan cara melihat pengujian Scatterplot. Di dalam pengujian Scatterplot ini ada menyajikan data antara regression standardized predicted value dan regression studentized residual, tidak ada terjadi heteroskedastisitas jika tidak ada pola 
yang jelas dan titik-titiknya tersebar dibawah dan diatas angka 0 pada sumbu Y. Sebuah model regresi yang dapat dikatakan bagus apabila tidak ada terjadi heteroskedastisitas (Imam Ghozali, 2006:105).”

\section{Pengujian Autokorelasi}

"Di dalam penelitian ini menggunakan pengujian autokorelasi yang bertujuan untuk melakukan pengujian apakah di dalam sebuah model regresi linear ada terjadi korelasi antara kesalahan pengganggu pada periode $\mathrm{t}$ dengan kesalahan pengganggu pada periode $\mathrm{t}-1$ ataupun dengan periode yang sebelumnya. Sebuah model regresi yang dapat dikatakan bagus apabila terbebas dari autokorelasi. Untuk dapat menentukan sebuah data itu mempunyai autokorelasi atau tidak dengan cara menggunakan Durbin-Watson. Apabila d terletak diantara dU dan (4dU), dapat memberikan kesimpulan bahwa hipotesis nolnya diterima, dan ini memberikan kesimpulan bahawa tidak ada terjadi autokorelasi (Imam Ghozali, 2006:95-96)."

\section{Analisis Regresi Berganda}

Di dalam penelitian ini, memakai analisis regresi berganda yang bertujuan untuk dapat menghitung intensitas dari hubungan yang terjadi diantara dua variabel ataupun lebih variabel, dan juga menciptakan prediksi perkiraan nilai $\mathrm{Y}$ atas nilai $\mathrm{X}$. Peneliti mempergunakan analisis regresi berganda dan hal ini dikarenakan di dalam penelitian ini mempunyai variabel independen yang lebih dari satu dan analisis tersebut dapat menguji apakah pembiayaan musyarakah $\left(\mathrm{X}_{1}\right)$, market share $\left(\mathrm{X}_{2}\right)$ dan modal intelektual $\left(\mathrm{X}_{3}\right)$ dapat berpengaruh terhadap kinerja keuangan (Y) pada BUS. Model regresi berganda yang akan digunakan oleh peneliti di dalam melakukan pengujian hipotesis ialah sebagai berikut ini:

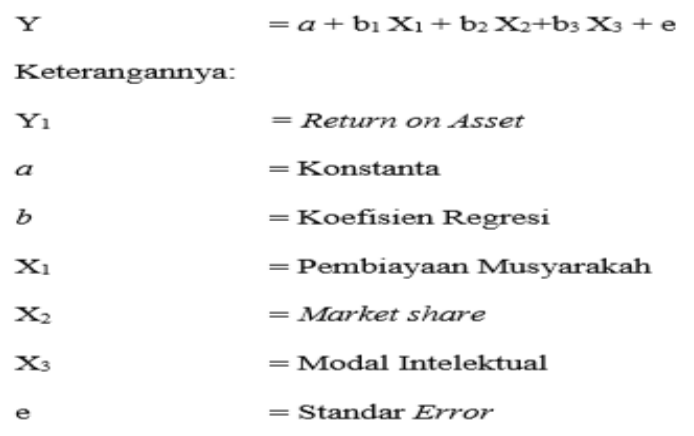

\section{Pengujian Koefisien Determinasi}

"Pada penelitian ini ada pengujian koefisien determinasi yang bertujuan untuk mengukur kemampuan dari suatu model regresi di dalam menerangkan mengenai variasi di dalam variabel dependen dan nilai dari koefisien determinasi ini bisa diukur dengan nilai $\mathrm{R}^{2}$ ataupun Adjusted $R$-Square. Nilai koefisien determinasi $\left(R^{2}\right)$ yang mendekati 1 menunjukkan bahwa variabel independen dapat memberikan hampir semua informasi yang diperlukan untuk dapat memprediksikan variasi variabel dependen, sedangkan nilai dari koefisien determinasi $\left(\mathrm{R}^{2}\right)$ yang kecil berarti bahwa kemampuan dari variabel independen di dalam menjelaskan variabel dependen terbatas. $\mathrm{R}^{2}$ ini mempunyai kelemahan yaitu bias terhadap jumlah variabel independen yang dimasukkan model, maka pada penelitian ini, peneliti lebih menggunakan Adjusted $R$-Square. Apabila nilai dari Adjusted $R$-Square yang mendekati 1, ini berarti bahwa akan semakin bagus/ baik kemampuan dari model di dalam menjelaskan variabel dependen (Imam Ghozali, 2006:83)."

\section{Pengujian Secara Parsial}

Pada pengujian ini ada menggunakan pengujian parsial yang memiliki tujuan untuk menunjukkan tingkat pengaruh antara satu variabel independen secara individual di dalam menerangkan variabel dependen. Pada pengujian parsial ini dapat dilakukan dengan beberapa cara yaitu seperti berikut:

a) "Dengan menggunakan $t_{\text {tabel }}$ dengan $t_{\text {hitung. }}$. Apabila $t_{\text {hitung }}>$ dari $t_{\text {tabel }}$, dapat berarti bahwa hipotesis alternatif diterima. Dapat dikatakan bahwa, dengan diterimanya hipotesis alternatif, maka ini berarti bahwa variabel independen secara individual dapat mempengaruhi variabel dependennya. Dan dengan menggunakan nilai signifikan level 5\%. Apabila nilai signifikansinya lebih kecil dari 5\%, dapat berarti bahwa hipotesis alternatif diterima dan juga dapat berarti bahwa pengaruh dari variabel independen terhadap variabel dependen signifikan (Raharjo, 2019)."

b) "Dengan menggunakan kurva pengujian hipotesis. Hipotesis alternatif dapat diterima apabila berada di daerah penolakan hipotesis nol. Melakukan pengujian hipotesis dengan menggunakan kurva sangat bermanfaat apabila nilai $t_{\text {hitung }}$ bernilai negatif. Apabila nilai $t_{\text {hitung }}$ 
negatif, maka pengujian hipotesis dilakukan disisi kiri dan apabila nilai $t_{\text {hitung }}$ positif, maka pengujian hipotesis dilakukan disisi kanan (Sarwono, Tanpa Tahun)."

\section{Pengujian Secara Simultan}

Pada pengujian ini ada menggunakan pengujian secara simultan yang bertujuan untuk meneliti bagaimana pengaruh dari semua variabel independen secara simultan terhadap variabel dependen. Di dalam aplikasi SPSS hasil dari pengujian secara simultan ini dapat dilihat dari tabel ANOVA ${ }^{\mathrm{a}}$.

Pengujian secara simultan ini juga dapat dilakukan dengan beberapa cara yaitu seperti berikut:

a) "Dengan menggunakan $F_{\text {tabel }}$ dengan $F_{\text {hitung. }}$. Apabila $\mathrm{F}_{\text {hitung }}>$ dari $\mathrm{F}_{\text {tabel }}$, dapat berarti bahwa hipotesis alternatif diterima. Dapat dikatakan bahwa, dengan diterimanya hipotesis alternatif, maka ini berarti bahwa secara simultan semua variabel independen mempunyai pengaruh terhadap variabel dependen (Raharjo, 2019)."

b) "Dengan menggunakan nilai signifikan level $5 \%$. Apabila nilai signifikansinya lebih kecil dari 5\%, dapat berarti bahwa hipotesis alternatif diterima dan juga dapat berarti bahwa secara simultan semua variabel independen mempunyai pengaruh yang signifikan terhadap variabel dependen (Raharjo, 2019).”

\section{$4 \quad$ Hasil Dan Pembahasan \\ Hasil Penelitian \\ Deskripsi Objek Penelitian}

Pada penelitian ini menggunakan objek penelitian BUS dan menggunakan teknik purposive sampling untuk mengambil sampel serta menggunakan data panel unbalanced. Hal ini dikarenakan unit dari cross-sectional mempunyai total pengamatan time series yang tidak sama. Menurut data dari statistik perbankan syariah (SPS) jumlah populasi BUS yang ada sebanyak 14 bank dan peneliti hanya menggunakan 13 BUS, dikarenakan 13 bank syariah itu sudah dapat memenuhi kesemua kriteria yang telah ditetapkan oleh peneliti. Tabel berikut menampilkan total sampel yang bisa digunakan di dalam penelitian ini.

\begin{tabular}{|l|l|c|c|}
\hline No. & \multicolumn{1}{|c|}{ Keterangan } & Jumlah & Persentase \\
\hline 1. & $\begin{array}{l}\text { Jumlah data pengamatan yang tersedia dari } 13 \\
\text { BUS }\end{array}$ & 68 & $100 \%$ \\
\hline 2. & Data outlier & 8 & $11,76 \%$ \\
\hline 3. & Jumlah data yang dapat diolah & 60 & $88,24 \%$ \\
\hline
\end{tabular}

Sumber: Hasil pengolahan data di SPSS (2020)

\section{Analisis Statistik Deskriptif}

Tabel berikut menampilkan hasil pengujian statistik deskriptif pada penelitian ini.

\begin{tabular}{|l|c|r|r|r|c|}
\hline Variabel & $\mathbf{N}$ & Minimum & Maksimum & Mean & Std. Deviation \\
\hline \multicolumn{1}{|c|}{ ROA } & 60 & $-1,74$ & 3,13 & 0,7382 & 0,77013 \\
\hline $\begin{array}{l}\text { Pembiayaan } \\
\text { Musyarakah }\end{array}$ & 60 & 0,58 & 89,07 & 32,1998 & 21,63012 \\
\hline $\begin{array}{l}\text { Market } \\
\text { Share }\end{array}$ & 60 & 0,59 & 37,75 & 9,6062 & 10,93235 \\
\hline $\begin{array}{l}\text { Modal } \\
\text { Intelektual }\end{array}$ & 60 & $-3,58$ & 4,30 & 1,8187 & 1,12375 \\
\hline
\end{tabular}

Sumber: Output Hasil Pengolahan Data SPSS 23 (2020)

\section{Pengujian Asumsi Klasik \\ Pengujian Normalitas}

Tabel berikut dapat menampilkan hasil pengujian normalitas.

\begin{tabular}{|ll|r|}
\hline \multicolumn{2}{|c|}{ One-Sample Kolmogorov-Smirnov Test } \\
\hline N & & \multicolumn{1}{|c|}{ Unstandardized Residual } \\
Normal Parameters & Mean & 60 \\
& Std. &, 0000000 \\
& Deviation &, 38495158 \\
Most Extreme & Absolute &, 118 \\
Differences & Positive &, 118 \\
& Negative &,- 075 \\
Test Statistic & &, 118 \\
Asymp. Sig. (2-tailed) & &, $036^{c}$ \\
Exact Sig. (2-tailed) & &, 342 \\
Point Probability &, 000 \\
\hline
\end{tabular}

Bersumber pada tabel tersebut dapat dilihat bahwasannya nilai dari Exact Sig. (2-tailed) yang mempunyai nilai sebesar $0.342>$ dari 0.05 dan hal ini dapat bermakna bahwasannya data mempunyai distribusi normal.

\section{Pengujian Multikolonieritas}

Tabel berikut ini menampilkan hasil pengujian multikolonieritas.

\begin{tabular}{|c|c|c|c|}
\hline \multicolumn{4}{|c|}{ Coefficients $^{\mathrm{a}}$} \\
\hline \multirow{2}{*}{\multicolumn{2}{|c|}{ Model }} & \multicolumn{2}{|c|}{ Collinearity Statistics } \\
\hline & & Tolerance & VIF \\
\hline \multirow[t]{4}{*}{1} & (Constant) & & \\
\hline & PM & 894 & 1,119 \\
\hline & MS & 970 & 1,031 \\
\hline & MI & 921 & 1,086 \\
\hline
\end{tabular}

Sumber: Output Hasil Pengolahan Data SPSS 23 (2020) 
Tabel tersebut menunjukkan bahwasannya nilai dari tolerance untuk kesemua variabel independen lebih besar daripada 0.10 dan juga nilai dari VIP yang lebih kecil dari 10 dan hal ini berarti bahwa model regresi di dalam penelitian ini tidak ada terjadi gejala multikolonieritas diantara variabel independennya.

\section{Pengujian Heteroskendastisitas}

Grafik berikut menampilkan hasil pengujian heteroskedastisitas.

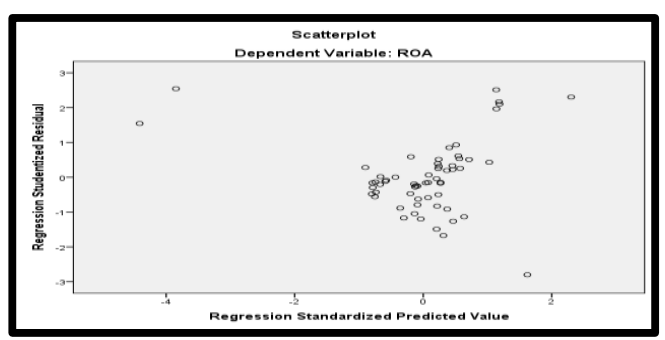

Sumber: Output Hasil Pengolahan Data SPSS 23 (2020)

Grafik berikut dapat menunjukkan bahwasannya kesemua titik-titik mempunyai sebaran secara acak dan tersebar baik di bawah ataupun di atas angka 0 pada sumbu Y dan hal ini berarti bahwa model regresi tidak ada terjadi gejala heteroskedastisitas, sehingga model regresi dapat digunakan untuk memprediksi ROA berdasarkan masukkan dari variabel independen.

\section{Pengujian Autokorelasi}

Tabel berikut menampilkan hasil pengujian autokorelasi.

\begin{tabular}{|l|c|r|c|r|r|}
\hline \multicolumn{7}{|c|}{ Model Summary $^{\mathrm{b}}$} \\
\hline Model & $\mathrm{R}$ & R Square & $\begin{array}{l}\text { Adjusted R } \\
\text { Square }\end{array}$ & $\begin{array}{c}\text { Std. Error of } \\
\text { the Estimate }\end{array}$ & $\begin{array}{r}\text { Durbin- } \\
\text { Watson }\end{array}$ \\
\hline 1 &, $866^{\mathrm{a}}$ &, 750 &, 737 &, 39513 & 2,237 \\
\hline
\end{tabular}

Sumber: Output Hasil Pengolahan Data SPSS 23 (2020)

Tabel tersebut dapat memperlihatkan bahwasannya nilai DW sebesar 2.237. Berdasarkan tabel durbin-watson dengan jumlah variabel independen sebanyak 3 variabel dan jumlah sampel pengamatan sebanyak 60 data, maka dapat diketahui nilai dari dL sebesar 1.4797 dan nilai dU sebesar 1.6889. Sebuah model regresi dapat dikatakan tidak terjadi autokorelasi apabila nilai DW berada diantara nilai dU dan 4-dU. Nilai 4-dU ialah sebesar 2.3111, sehingga dapat diketahui bahwa nilai DW berada diantara nilai dU dan $4-d U(1.6889<2.237<2.3111)$. Jadi, dapat disimpulkan bahwa model regresi tidak ada terjadi gejala autokorelasi.

\section{Pengujian Hipotesis}

\section{Hasil Pengujian Regresi Linier Berganda}

Tabel berikut menampilkan hasil pengujian regresi linier berganda.

\begin{tabular}{|c|c|c|c|c|c|c|}
\hline \multicolumn{7}{|c|}{ Coefficients $^{\mathrm{a}}$} \\
\hline & & \multicolumn{2}{|c|}{$\begin{array}{l}\text { Unstandardized } \\
\text { Coefficients }\end{array}$} & \multirow{2}{*}{$\begin{array}{c}\text { Standardized } \\
\text { Coefficients } \\
\text { Beta }\end{array}$} & \multirow[b]{2}{*}{ t } & \multirow[b]{2}{*}{ Sig. } \\
\hline \multicolumn{2}{|c|}{ Model } & B & Std. Error & & & \\
\hline 1 & (Constant) &, 149 &, 155 & & 961 & 341 \\
\hline & PM &,- 008 &, 003 &,- 238 & $-3,363$ & 001 \\
\hline & MS &,- 010 &, 005 &,- 141 & $-2,084$ &, 042 \\
\hline & MI & 526 & 048 & 768 & 11,027 & 000 \\
\hline
\end{tabular}

Sumber: Output Hasil Pengolahan Data SPSS 23 (2020)

Persamaan regresi linier berganda yang didapatkan dari hasil pengujian regresi linier berganda pada tabel 4.6 ialah sebagai berikut:

$$
Y=0.149-0.008 X_{1}-0.010 X_{2}+0.526 X_{3}+\varepsilon
$$

Bersumber pada persamaan regresi tersebut, maka bisa ditarik beberapa kesimpulan sebagai berikut:

1. Konstanta $(\alpha)$ pada penelitian ini mempunyai nilai sebesar 0.149 dan hal ini bermakna apabila pembiayaan musyarakah, market share dan modal intelektual dianggap konstan, maka besarnya nilai ROA pada BUS pada tahun 2013-2018 sebesar 0.149 .

2. Koefisien regresi pada variabel pembiayaan musyarakah mempunyai nilai sebesar -0.008 dan hal ini bermakna setiap adanya peningkatan pada variabel pembiayaan musyarakah sebesar 1 kali, maka besarnya nilai ROA pada BUS akan menurun sebesar 0.008 dengan anggapan bahwa variabel lainnya konstan.

3. Koefisien regresi pada variabel market share mempunyai nilai sebesar -0.010 dan hal ini bermakna setiap adanya peningkatan pada variabel market share sebesar 1 kali, maka besarnya nilai ROA pada BUS akan menurun sebesar 0.010 dengan anggapan bahwa variabel lainnya konstan.

4. Koefisien regresi pada variabel modal intelektual mempunyai nilai sebesar 0.526 dan hal ini 
bermakna setiap adanya peningkatan pada variabel modal intelektual sebesar 1 kali, maka besarnya nilai ROA pada BUS akan meningkat sebesar 0.526 dengan anggapan bahwa variabel lainnya konstan.

\section{Hasil Pengujian Hipotesis Secara Simultan}

Tabel berikut menampilkan hasil pengujian hipotesis secara simultan.

\begin{tabular}{|c|c|c|c|c|c|}
\hline \multicolumn{6}{|c|}{ ANOVA $^{a}$} \\
\hline Model & $\begin{array}{l}\text { Sum of } \\
\text { Squares }\end{array}$ & df & Mean Square & F & Sig. \\
\hline 1 Regression & 26,250 & 3 & 8,750 & 56,044 &, $000^{6}$ \\
\hline Residual & 8,743 & 56 & , 156 & & \\
\hline Total & 34,993 & 59 & & & \\
\hline
\end{tabular}

Sumber: Output Hasil Pengolahan Data SPSS 23 (2020)

Tabel tersebut dapat menunjukkan bahwasannya nilai $\mathrm{F}_{\text {hitung }}$ sebesar 56.044 dan nilai signifikansinya sebesar 0.000. Apabila dilihat dari nilai $\mathrm{F}_{\text {hitung }}$ dan $\mathrm{F}_{\text {tabel }}$, maka nilai dari $\mathrm{F}_{\text {hitung }}$ sebesar 56.044 dan nilai $\mathrm{F}_{\text {tabel }}$ sebesar 2.77, sehingga dapat diketahui bahwa nilai dari $\mathrm{F}_{\text {hitung }}>$ daripada nilai $\mathrm{F}_{\text {tabel. }}$. Dapat ditarik kesimpulan bahwa secara simultan semua variabel independen berpengaruh terhadap variabel dependen. Apabila dilihat dari nilai signifikansi yang lebih kecil dari 0.05, maka dapat ditarik kesimpulan bahwa variabel pembiayaan musyarakah, market share dan modal intelektual berpengaruh secara simultan dan signifikan terhadap ROA pada BUS di Indonesia pada tahun 2013-2018. Dengan demikian, hipotesis keempat yang berbunyi pembiayaan musyarakah, market share dan modal intelektual berpengaruh secara simultan terhadap kinerja keuangan pada bank umum syariah diterima (Hipotesis keempat diterima).

\section{Hasil Pengujian Hipotesis Secara Parsial}

"Pada penelitian ini menggunakan pengujian hipotesis secara parsial yang bertujuan untuk mengetahui bagaimana pengaruh dari masing-masing variabel independen terhadap variabel dependen. Hipotesis alternatif dapat diterima apabila mempunyai nilai $t_{\text {hitung }}>$ daripada nilai $t_{\text {tabel }}$ dengan syarat nilai $t_{\text {hitung }}$ bernilai positif, apabila nilai $t_{\text {hitung }}$ bernilai negatif, maka hipotesis alternatif diterima apabila $t_{\text {hitung }}$ $<$ dari $t_{\text {tabel. }}$ Tingkat signifikansi juga dapat menentukan sebuah hipotesis alternatif dapat diterima ataupun ditolak, apabila tingkat signifikansi lebih kecil dari 0.05 , maka hipotesis alternatif diterima. Kurva pengujian hipotesis dapat juga menentukan hipotesis alternatif diterima ataupun ditolak, apabila nilai dari $t_{\text {hitung }}$ berada di daerah penolakan hipotesis nol, maka ini berarti bahwa hipotesis alternatif diterima (Carsel, 2018:35)." Tabel berikut menampilkan hasil pengujian hipotesis secara parsial.

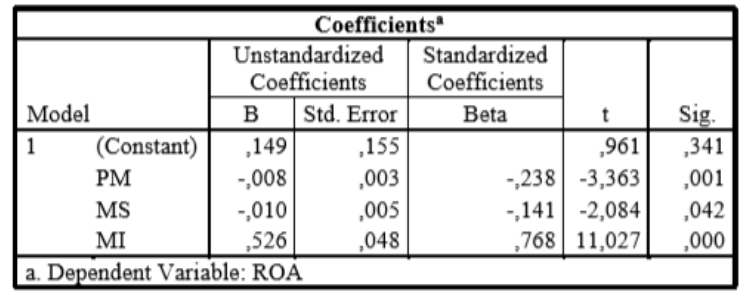

Sumber: Output Hasil Pengolahan Data SPSS 23 (2020)

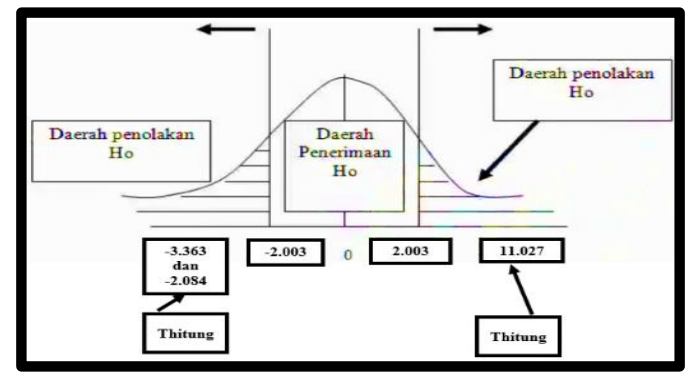

Berdasarkan data dari tabel tersebut dapat ditarik beberapa kesimpulan seperti:

1. Variabel pembiayaan musyarakah $\left(\mathrm{X}_{1}\right)$ mempunyai nilai signifikansi sebesar 0.001 dan nilai $t_{\text {hitung }}-3.363$. Apabila dilihat dari nilai $t_{\text {hitung }}$ dan $t_{\text {tabel }}$, maka nilai dari $t_{\text {hitung }}$ sebesar -3.363 dan nilai $t_{\text {tabel }}$ sebesar -2.003 , sehingga dapat diketahui bahwa nilai dari $\mathrm{t}_{\text {hitung }}<$ daripada nilai $\mathrm{t}_{\text {tabel }}$ dan hal ini berarti bahwa hipotesis alternatif diterima. Apabila dilihat pada gambar daerah penerimaan/penolakan Ho dan Ha, $t_{\text {hitung }}-3.363$ berada di dalam daerah penolakan Ho dan ini berarti bahwa Ha diterima. Apabila dilihat dari nilai signifikansi yang lebih kecil dari 0.05, maka dapat bermakna bahwa variabel pembiayaan musyarakah berpengaruh secara signifikan terhadap kinerja keuangan. Dengan demikian, hipotesis pertama yang berbunyi pembiayaan musyarakah berpengaruh terhadap kinerja keuangan pada bank umum syariah diterima (Hipotesis pertama diterima). 
2. Variabel market share $\left(\mathrm{X}_{2}\right)$ mempunyai nilai signifikansi sebesar 0.042 dan nilai $t_{\text {hitung }}-2.084$. Apabila dilihat dari nilai $\mathrm{t}_{\text {hitung }}$ dan $\mathrm{t}_{\text {tabel }}$, maka nilai dari $t_{\text {hitung }}$ sebesar -2.084 dan nilai $t_{\text {tabel }}$ sebesar 2.003, sehingga dapat diketahui bahwa nilai dari $\mathrm{t}_{\text {hitung }}<$ daripada nilai $\mathrm{t}_{\text {tabel }}$ dan hal ini berarti bahwa hipotesis alternatif diterima. Apabila dilihat pada gambar daerah penerimaan/penolakan Ho dan $\mathrm{Ha}, \mathrm{t}_{\text {hitung }}-2.084$ berada di dalam daerah penolakan Ho dan ini berarti bahwa Ha diterima. Apabila dilihat dari nilai signifikansi yang lebih kecil dari 0.05, maka dapat bermakna bahwa variabel market share berpengaruh secara signifikan terhadap kinerja keuangan. Dengan demikian, hipotesis kedua yang berbunyi market share berpengaruh terhadap kinerja keuangan pada bank umum syariah diterima (Hipotesis kedua diterima).

3. Variabel modal intelektual $\left(\mathrm{X}_{3}\right)$ mempunyai nilai signifikansi sebesar 0.000 dan nilai $t_{\text {hitung }}$ 11.027. Apabila dilihat dari nilai $t_{\text {hitung }}$ dan $t_{\text {tabel }}$, maka nilai dari $t_{\text {hitung }}$ sebesar 11.027 dan nilai $t_{\text {tabel }}$ sebesar 2.003, sehingga dapat diketahui bahwa nilai dari $t_{\text {hitung }}>$ daripada nilai $t_{\text {tabel }}$ dan hal ini berarti bahwa hipotesis alternatif diterima. Apabila dilihat pada gambar daerah penerimaan/penolakan Ho dan $\mathrm{Ha}, \mathrm{t}_{\text {hitung }} 11.027$ berada di dalam daerah penolakan Ho dan ini berarti bahwa Ha diterima. Apabila dilihat dari nilai signifikansi yang lebih kecil dari 0.05, maka dapat bermakna bahwa variabel modal intelektual berpengaruh secara signifikan terhadap kinerja keuangan. Dengan demikian, hipotesis ketiga yang berbunyi modal intelektual berpengaruh terhadap kinerja keuangan pada bank umum syariah diterima (Hipotesis ketiga diterima).

\section{Pengujian Koefisien Determinasi}

Tabel berikut menampilkan hasil pengujian koefisien determinasi.

\begin{tabular}{|l|c|r|r|r|r|}
\hline \multicolumn{7}{|c|}{ Model Summarr $^{\text {b }}$} \\
\hline Model & R & R Square & $\begin{array}{c}\text { Adjusted R } \\
\text { Square }\end{array}$ & $\begin{array}{r}\text { Std. Error of } \\
\text { the Estimate }\end{array}$ & $\begin{array}{r}\text { Durbin- } \\
\text { Watson }\end{array}$ \\
\hline 1 &, $866^{\mathrm{a}}$ &, 750 &, 737 &, 39513 & 2,237 \\
\hline $\begin{array}{l}\text { a. Predictors: (Constant), MI, MS, PM } \\
\text { b. Dependent Variable: ROA }\end{array}$ \\
\hline
\end{tabular}

Sumber: Output Hasil Pengolahan Data SPSS 23 (2020)
Tabel tersebut dapat menunjukkan bahwa nilai dari Adjusted R-Square sebesar 0.737 atau sebesar $73.7 \%$ dan hal ini berarti bahwa $73.7 \%$ variasi dari variabel ROA pada BUS tahun 2013-2018 disebabkan oleh ketiga variabel independen yang ada di dalam penelitian ini. Ketiga variabel independen tersebut ialah pembiayaan musyarakah, market share dan modal intelektual. Selanjutnya, sekitar $26.3 \%$ variasi dari variabel ROA dapat dijelaskan oleh variabel lain yang tidak diteliti di dalam penelitian ini.

\section{Pembahasan Hasil Penelitian}

\section{Pengaruh Pembiayaan Musyarakah terhadap Kinerja Keuangan}

Hasil dari pengujian hipotesis memperlihatkan bahwa variabel pembiayaan musyarakah mempunyai nilai koefisien sebesar -0.008 dan tingkat signifikansi sebesar $0.001<0.05$ yang berarti pembiayaan musyarakah berpengaruh secara signifikan terhadap kinerja keuangan bank umum syariah tahun 20132018.

Pembiayaan musyarakah termasuk ke dalam kelompok pembiayaan bagi hasil laba yang mempunyai pengaruh yang signifikan terhadap kinerja keuangan, khususnya terhadap tingkat ROA pada BUS di Indonesia, akan tetapi arah pengaruhnya tidak searah atau berlawanan. Hal ini berarti bahwa apabila komposisi pembiayaan musyarakah ditingkatkan, maka akan berdampak pada penurunan ROA pada BUS dan apabila komposisi pembiayaan musyarakah diturunkan, maka akan berdampak pada peningkatan ROA.

Penyebab variabel pembiayaan musyarakah mempunyai hubungan yang tidak searah dengan ROA ialah pembiayaan musyarakah mempunyai berbagai risiko yang pada akhirnya berdampak terhadap tingkat ROA seperti pembiayaan musyarakah yang telah diberikan oleh BUS tidak dapat tertagih kepada nasabahnya, bisnis yang dijalankan oleh para nasabah mengalami kerugian, sehingga bank juga ikut menanggung kerugian, bisnis yang dijalankan nasabah mengalami kebangkrutan, nasabah yang tidak jujur di dalam melaporkan jumlah keuntungan yang telah didapatkan dalam bisnis yang telah dijalankannya.

Semakin tinggi tingkat risiko pembiayaan bermasalah, maka akan dapat menurunkan tingkat pendapatan bank syariah dan pada akhirnya bisa berdampak pada penurunan tingkat ROA. Selain risiko 
pembiayaan bermasalah, risiko bisnis yang dijalankan oleh nasabah mengalami kerugian juga dapat membuat pendapatan bank syariah menurun. Di dalam akad musyarakah kerugian harus dibagi berdasarkan kesepakatan bersama dan semua pihak baik bank dan nasabah harus menanggung segala macam kerugian. Maka, pada saat bisnis yang dijalankan nasabah yang menerima pembiayaan musyarakah mengalami kerugian, maka kerugian harus ditanggung secara bersama dan hal ini dapat membuat pendapatan bank syariah menjadi menurun untuk menutupi kerugian dari bisnis tersebut.

Faktor lainnya yang dapat membuat arah pengaruh pembiayaan musyarakah tidak searah dengan tingkat ROA ialah adanya nasabah yang tidak jujur di dalam melaporkan keuntungan bisnis yang telah didapatkan, sehingga bisa mengurangi jumlah pendapatan yang diterima oleh bank syariah. Di dalam pembiayaan musyarakah, keuntungan yang didapatkan oleh bank syariah tidak dapat ditentukan diawal berapa besar nominalnya, hanya ditentukan berapa persentasenya saja. Apabila nasabah melaporkan pendapatan sedikit, maka bank akan mendapatkan penghasilan yang sedikit juga.

Apabila bank mendapatkan pendapatan dari pembiayaan musyarakah sedikit, maka dapat membuat laba bank menjadi sedikit juga, sehingga tingkat pengembalian atas aset (ROA) menjadi menurun. Hasil penelitian ini sejalan dengan penelitian yang telah dilakukan oleh Almunawwaroh \& Marliana, (2017); Faradilla, Arfan, \& Shabri, (2017); Puteri, Meutia, \& Yuniartie, (2014); Romdhoni \& Yozika, (2018) yang mengatakan bahwa variabel pembiayaan musyarakah berpengaruh secara signifikan terhadap kinerja keuangan.

\section{Pengaruh Market Share terhadap Kinerja Keuangan}

Hasil dari pengujian hipotesis memperlihatkan bahwa variabel market share mempunyai nilai koefisien sebesar -0.010 dan tingkat signifikansi sebesar $0.042<0.05$ yang berarti market share berpengaruh secara signifikan terhadap kinerja keuangan pada BUS tahun 2013-2018.

Market share mempunyai pengaruh yang signifikan terhadap kinerja keuangan, khususnya terhadap tingkat ROA pada BUS di Indonesia dan arah pengaruh tersebut tidak searah atau berlawanan. Ini berarti bahwa apabila market share DPK meningkat, maka akan berdampak pada penurunan ROA dan apabila market share DPK menurun, maka akan berdampak pada peningkatan ROA di BUS.

Penyebab variabel market share pada BUS mempunyai hubungan yang tidak searah dengan ROA ialah adanya ketidakefisienan dari bank umum syariah (BUS) di dalam menggunakan dana dari nasabahnya untuk mendapatkan keuntungan yang maksimal dan tingginya tingkat bagi hasil yang diberikan BUS kepada para pemilik dana investasi (pemilik DPK), sehingga secara langsung dapat menurunkan laba bank syariah. Menurut data dari Statistik Perbankan Syariah (SPS) tahun 2019, dapat diketahui bahwa bagi hasil yang diberikan BUS kepada para pemilik dana investasi sebesar $53.30 \%$ dari total pendapatan operasional yang diterima oleh bank dan pihak bank hanya mendapatkan sebesar $46.7 \%$ dari total pendapatan operasionalnya. Hal tersebut secara langsung bisa membuat laba bank menjadi rendah dan apabila bank bisa mendapatkan porsi yang lebih besar dari $46.7 \%$, maka akan dapat menguntungkan bank.

Penyebab lainnya yang membuat variabel market share DPK pada BUS mempunyai hubungan yang tidak searah dengan ROA ialah karena sebagian besar dana dari pihak ketiga digunakan oleh BUS di dalam berbagai bentuk pembiayaan syariah dan risiko dari pembiayaan bermasalah di dalam BUS cukup tinggi, bahkan pernah mencapai $6.17 \%$ pada bulan Mei tahun 2016 (SPS, 2019), sehingga akan mempengaruhi tingkat ROA pada BUS. Semakin tinggi risiko pembiayaan bermasalah, maka akan semakin rendah pendapatan yang diterima bank dan akan berdampak pada penurunan tingkat ROA.

"Menurut Fahmi, (2012) dalam Ibrahim, Nuzula, \& Nurlaily, (2019) seharusnya BUS tidak hanya mengedepankan market share untuk bisa mendapatkan profit dan hal ini dikarenakan tingkat profitabilitas di dalam BUS lebih bersumber dari tingkat efisiensi daripada adanya penguasaaan pasar yang tinggi. Apabila bank tidak efisien di dalam menggunakan dananya, maka dapat membuat tingkat profitabilitas bank tersebut menjadi buruk." Hasil penelitian ini sejalan dengan penelitian yang telah dilakukan oleh Setyawati, (2016); Sudana \& Sulistyowati, (2010); Obeidat, El-Rimawi, Masa'deh, Maqableh, \& Al-Jarrah, (2013) yang mengatakan 
bahwa variabel market share berpengaruh secara signifikan terhadap kinerja keuangan.

\section{Pengaruh Modal Intelektual terhadap Kinerja Keuangan}

Hasil dari pengujian hipotesis memperlihatkan bahwa variabel modal intelektual mempunyai nilai koefisien sebesar 0.526 dan tingkat signifikansi sebesar $0.000<0.05$ yang berarti modal intelektual berpengaruh secara signifikan terhadap kinerja keuangan pada BUS tahun 2013-2018.

Modal intelektual mempunyai pengaruh yang signifikan terhadap kinerja keuangan, khususnya terhadap tingkat ROA pada BUS di Indonesia dan arah pengaruh tersebut searah. Ini berarti bahwa apabila modal intelektual meningkat di dalam BUS, maka akan berdampak pada peningkatan ROA. Komponen dari modal intelektual ada 3 di dalam penelitian ini yaitu, human capital, structural capital, dan capital employed. Kesemua komponen dari modal intelektual tersebut menjadi satu-kesatuan yang dapat meningkatkan ROA pada BUS.

Bank syariah dapat memperoleh kinerja keuangan yang tinggi apabila mempekerjakan karyawan yang mempunyai kompentensi tinggi. Karyawan yang berkompetensi tinggi mampu untuk bekerja dengan sangat baik dan juga mampu untuk mengambil berbagai kebijakan dan keputusan yang dapat menguntungkan bagi bank syariah. Bank syariah dapat memberikan pelatihan kepada para karyawannya untuk mendapatkan human capital yang berkompetensi tinggi. Karyawan dapat bekerja dengan maksimal, apabila bank syariah mempunyai structural capital yang dapat mendukung para karyawan untuk bekerja, seperti mempunyai budaya organisasi yang bagus, iklim kerja yang bagus, struktur organisasi yang tertata. Bank syariah juga dapat memperoleh kinerja keuangan yang tinggi apabila dapat menggunakan capital employed dengan sebaik mungkin dan seefisien mungkin.

Hasil penelitian ini didukung oleh teori dari resources based view (RBV) yang mengatakan bahwa sebuah perusahaan dapat memperoleh keunggulan di dalam pesaingan bisnisnya dan juga memperoleh kinerja keuangan yang baik yaitu dengan mempunyai, menguasai, dan juga memanfaatkan semua aset strategis yang penting yang ada di dalam perusahaan, baik itu berupa aset yang tidak berwujud dan aset yang berwujud. Hasil penelitian ini sejalan dengan penelitian yang telah dilakukan oleh Bustamam \& Aditia, (2016); Ousama \& Fatima, (2015); Lestari, Paramu, \& Sukarno, (2017); Lestari et al., (2017) yang mengatakan bahwa variabel modal intelektual berpengaruh secara signifikan terhadap kinerja keuangan.

\section{Kesimpulan, Keterbatasan Dan Saran Kesimpulan}

1. Hipotesis pertama diterima yang artinya pembiayaan musyarakah berpengaruh terhadap kinerja keuangan pada bank umum syariah di Indonesia.

2. Hipotesis kedua diterima yang artinya market share berpengaruh terhadap kinerja keuangan pada bank umum syariah di Indonesia.

3. Hipotesis ketiga diterima yang artinya modal intelektual berpengaruh terhadap kinerja keuangan pada bank umum syariah di Indonesia.

4. Hipotesis keempat diterima yang artinya pembiayaan musyarakah, market share, dan modal intelektual berpengaruh secara bersamasama terhadap kinerja keuangan pada bank umum syariah di Indonesia.

\section{Keterbatasan Peneliti Pada Penelitian}

1. Sulitnya mendapatkan sumber buku yang membahas mengenai market share khusus untuk perbankan syariah, sehingga peneliti hanya dapat menggunakan artikel ilmiah untuk mencari sumber referensi.

2. Kurangnya sumber buku yang membahas secara lengkap mengenai modal intelektual pada perbankan syariah.

\section{Saran}

1. Peneliti selanjutnya dapat menggunakan program penggolahan data lainnya untuk menggolah data penelitian, seperti menggunakan program Eviews.

2. Peneliti selanjutnya dapat memperluas objek penelitiannya seperti meneliti pada unit usaha syariah (UUS) dan BPRS.

3. Peneliti selanjutnya dapat menambah beberapa variabel yang lainnya seperti variabel FDR, CAR, NPF dan inflasi untuk mengukur pengaruhnya terhadap kinerja keuangan perbankan syariah. 


\section{Daftar Pustaka}

Aisyiah, N., Darminto, \& Husaini, A. (2013). Pengukuran Kinerja Keuangan Perusahaan Menggunakan Metode Rasio Keuangan dan Metode EVA (Economic Value Added) (Studi Pada PT. Kalbe Farma Tbk) yang Terdaftar di Bursa Efek Indonesia Periode 2009-2011. Jurnal Administrasi Bisnis, 2(1), 108-117.

Almunawwaroh, M., \& Marliana, R. (2017). Analisis pengaruh pembiayaan musyarakah terhadap profitabilitas bank syariah di indonesia. Jurnal Akuntansi, 12(2), 177-190.

Ascarya, \& Yumanita, D. (2005). Bank Syariah: Gambaran Umum (14 ed.). Jakarta: Pusat Pendidikan dan Studi Kebanksentralan (PPSK).

Belkhaoui, S., Lakhal, L., Lakhal, F., \& Hellara, S. (2014). Market structure, strategic choices and bank performance: a path model. Managerial Finance, $\quad 40(6), \quad 538-564$. https://doi.org/10.1108/MF-07-2013-0183

Bustamam, \& Aditia, D. (2016). Pengaruh Intellectual Capital, Biaya Intermediasi dan Islamicity Performance Index Terhadap Profitabilitas Syariah di Indonesia. Jurnal Dinamika Akuntansi dan Bisnis, 3(1), 17-25.

Carsel, S. (2018). Metodologi Penelitian Kesehatan dan Pendidikan. Yogjakarta: Penebar Media Pustaka.

Dendawijaya, \& Lukman. (2005). Manajemen Perbankan. Jakarta: Ghalia Indonesia.

Endri, \& Wakil, A. (2008). Analisis Kinerja Keuangan Dengan Menggunakan Rasio-Rasio Keuangan Dan Economic Value Added ( Studi Kasus : PT . Bank Syariah Mandiri ). TAZKIA Islamic Finance \& Business Review, 3(2), 113-134.

Faradilla, C., Arfan, M., \& Shabri, M. (2017). Pengaruh Pembiayaan murabahah, Istishna, Mudharabah, dan Musyarakah Terhadap Profitabilitas Bank Umum Syariah di Indonesia. Jurnal Magister Akuntansi Pascasarjana
Universitas Syiah Kuala, 6(3), 10-18.

Farah, A., \& Sari, E. P. (2014). Modal Manusia dan Produktivitas. Journal of Economics and Policy, 7(1), 22-28.

Ghozali, I. (2006). Aplikasi Analisis Multivariate dengan Program SPSS. Semarang: Badan Penerbit Universitas Dipenegoro.

Hastuti, R. K. (2019). Perbankan Syariah Masih Sulit Bersaing Dengan Konvensional. Diambil 22 Desember 2019, dari CNBC Indonesia website: www.cnbcindonesia.com

Ibrahim, M., Nuzula, N. F., \& Nurlaily, F. (2019). Pengaruh Kecukupan Modal, Fungsi Intermediasi, Pembiayaan Bermasalah, Biaya Operasi, dan Pangsa Pasar Terhadap Profitabilitas Bank Syariah. Jurnal Administrasi Bisnis (JAB), 72(2), 175-185.

Ikatan Akuntan Indonesia. (2002). Pernyataan Standar Akuntansi Keuangan No.19. Jakarta: Salemba Empat.

Imam Ghozali. (2006). Aplikasi Analisis Multivariate dengan Program SPSS. 316.

Ismail. (2016). Perbankan Syariah. Jakarta: Prenadamedia Group.

Kehelwalatenna, S., \& Gunaratne, P. S. M. (2010). The Impact Of Intellectual Capital On The Firm Performance and Investor Response: An Empirical Study Of Selected Sectors In Colombo Stock Exchange. Proceedings of the 1st internasional conference on business and information, University of Kelaniya, 1-23.

Kuncoro, Mudrajad, \& Suhardjono. (2002). Manajemen Perbankan Teori dan Aplikasi. Jogjakarta: BPFE.

Lestari, S. D., Paramu, H., \& Sukarno, H. (2017). Pengaruh Intellectual Capital Terhadap Kinerja Keuangan Perbankan Syari'Ah Di Indonesia. EKUITAS (Jurnal Ekonomi dan Keuangan), 
20(3),

346. https://doi.org/10.24034/j25485024.y2016.v20.i3 .1838

Maghfuriyah, A., Azam, S. M. F., \& Shukri, S. (2019). Market Share and Islamic Banking Performance in Indonesia: An Error Correction Model. Management Science Letter, 1407-1418.

Mawaddah, N. (2015). Faktor-Faktor yang Mempengaruhi Profitabilitas Bank Syariah. Etikonomi, 14(2), 241-256.

Mehri, M., Umar, M. S., Saeidi, P., Hekmat, R. keyhani, \& Naslmosavi, S. (2013). Intellectual Capital and Firm Performance of High Intangible Intensive Industries: Malaysia Evidence. Asian Social Science, 9(9), 1-10.

Mehta, C. R., \& Patel, N. R. (2011). IBM SPSS Exact Tests. Armonk, NY: IBM Corporation.

Muhammad, N. M. N., \& Ismail, M. K. A. (2009). Intellectual Capital Efficiency and Firm's Performance: Study on Malaysian Financial Sectors. Internasioanl Journal of Economics and Finance, 1(2), 206-212.

Muslim. (2015). Pengaruh Pembiayaan Murabahah dan Musyarakah Terhadap Profitabilitas (Studi pada BPR Syariah di Indonesia). Universitas Syiah Kuala.

Nawawi, A., Nurdiansyah, D. H., \& Qodliyah, D. S. A. Al. (2018). Pengaruh Pembiayaan Mudharabah dan Musyarakah Terhadap Profitabilitas (ROA) Pada BPRS HIK Bekasi Kantor Cabang Karawang. FALAH: Jurnal Ekonomi Syariah, 3(2), 96. https://doi.org/10.22219/jes.v3i2.7679

Nawaz, T. (2017). Determinants of financial performance of Islamic banks: an intellectual capital perspective. Journal of Islamic Accounting and Business Research, 8(2), 130142. https://doi.org/10.1108/JIABR-06-20160071
Obeidat, B. Y., El-Rimawi, S. Y., Masa'deh, R. (Moh'd T., Maqableh, M. M., \& Al-Jarrah, I. M. (2013). Evaluating the Profitability of the Islamic banks in Jordan. European Journal of Economics, Finance and Administrative Sciences, (56), 27-37.

Ousama, A. A., \& Fatima, A. H. (2015). Intellectual capital and financial performance of Islamic banks. International Journal of Learning and Intellectual Capital, 12(1), 1-15. https://doi.org/10.1504/IJLIC.2015.067822

Prasetiyo, L. (2012). Perkembangan Bank Syariah Pasca UU 21 Tahun 2008. Al-Tahrir, 12(1), 4363.

Prastowo, D. (2008). Analisis Laporan Keuangan (2 ed.). Jogjakarta: YKPN.

Puteri, D. R., Meutia, I., \& Yuniartie, E. (2014). Pengaruh Pembiayaan Mudharabah,Musyarakah, Murabahah, Istishna Dan Ijarah Terhadap Profitabilitas Pada Bank Umum Syariah Di Indonesia. Akuntabilitas, 8(1), 1-24. https://doi.org/10.29259/JA.V8I1.8782

Rama, A. (2015). Analisis deskriptif perkembangan perbankan syariah di asia tenggara. Journal of Tauhidinomics, 1(2), 105-123.

Rofiatun, N. F. (2016). Pengaruh pangsa pasar dan indikator perbankan terhadap profitabilitas bank umum syariah Indonesia. Journal of Islamic Economics Lariba, 2(1), 13-24.

Rohman, S. N., \& Karsinah. (2016). Analisis Determinan Pangsa Pasar Bank Syariah dengan Kinerja Bank Syariah di Indonesia Periode 20112016. Economics Development Analysis Journal, 5(2), 135-142.

Romdhoni, A. H., \& Yozika, F. Al. (2018). Pengaruh Pembiayaan Mudharabah, Musyarakah Dan Ijarah Terhadap Profitabilitas Bank Muamalat Indonesia. Jurnal Ilmiah Ekonomi Islam, 4(3), 177-186. https://doi.org/10.29040/jiei.v4i03.314 
Saefullah, A. (2019). Upaya Penyelamatan Bank Muamalat Dipertanyakan. Diambil 22 Desember 2019, dari Kabarjatim website: kabarjatim.com

Samad, A. (2008). Market structure, conduct and performance: Evidence from the Bangladesh banking industry. 19, 181-193. https://doi.org/10.1016/j.asieco.2007.12.007

Sawarjuwono, T., \& Kadir, A. P. (2003). Intellectual Capital: Perlakuan Pengukuran dan Pelaporan (Sebuah Library Research). Jurnal Akuntansi dan Keuangan, 5(1), 35-57.

Setyawati, I. (2016). Determinants of Growth and Profitability by Bank Specific Variable and Market Structure in Islamic Banking in Indonesia. Academy of Strategic Management Journal, 15(3), 1-14.

Sudana, I. M., \& Sulistyowati, C. (2010). Pangsa Pasar Dana Pihak Ketiga dan Return On Assets Bank Umum di Indonesia. Majalah Ekonomi, 20(2), 154-169.

Ulum, I. (2009). Intellectual Capital: Konsep dan Kajian Empiris. Yogjakarta: Graha Ilmu.

Ulum, I. (2015). Intelektual Capital: Model Pengukuran, Framework Pengungkapan, dan Kinerja Organisasi. Universitas Muhammadiyah Malang. 